удК 351.84

DOI https://doi.org/10.32837/apdp.v0i88.3065

М. А. Погосян

\title{
МЕРЕЖА ІНТЕРНЕТ - СУЧАСНИЙ НАПРЯМ ОПТИМІЗАЦІЇ ПРАВОВОЇ КОМУНІКАЦІЇ МІЖ ПРАВООХОРОННИМИ, ПРАВОЗАХИСНИМИ ТА СУДОВИМИ ОРГАНАМИ
}

Постановка проблеми. У сучасному інформаційному світі зі зміною технологій та їхньої ролі в життедіяльності суспільства значно розширилася сфера обміну інформацією, що актуалізує розвиток інноваційних комунікацій. Розбудова правової держави, реформування судів різних інстанцій, правоохоронних та правозахисних органів зумовлюють нагальний розвиток дієвої правової комунікації між зазначеними органами. Упровадження електронної комерції свідчить про відсутність у нашій державі належного нормативно-правового регулювання та наукового забезпечення правової комунікації між правоохоронними, правозахисними та судовими органами. 3 огляду на зазначене, варто акцентувати увагу на тому, що питання, пов'язане із правовою комунікацією між правоохоронними, правозахисними та судовими органами в сучасному інформаційному суспільстві, привертає особливу увагу як вітчизняних, так і закордонних науковців. Через зростання кількості користувачів інтернету актуальності набуло вдосконалення поширення правоохоронними, правозахисними та судовими органами інформації зазначеною Мережею.

Аналіз останніх досліджень і публікацій. Питання, пов’язані з комунікацією, досліджували такі вітчизняні та закордонні вчені, як: С. Алексєєв, Д. Андрєєв, А. Антонов, Е. Афонін, О. Балинська, М. Білінська, Т. Бутирська, М. Василик, А. Войчак, Н. Грицяк, О. Дмитренко, Н. Дніпренко, Н. Луман, Л. Луц, А. Поляков, Г. Почепцов, Г. Прованшер, П. Рабінович, Н. Савінова, С. Серьогін, І. Ситар, Г. Ситник, А. Токарська, I. Честнов та інші. Інтернет-комунікацію як одну із проблем сутності інтернету вивчали: С. Алстром, В. Білоус, Н. Вінер, А. Гальчинський, Г. Грачов, М. Кастельс, В. Коляденко, Ю. Левенець, Г. Почепцов, Д. Рісмен, Д. Яковлев та інші. Проте наукові праці зазначених авторів переважно пов’язані з філософським аспектом комунікації й аналізом фундаментальних засад її функціонування в суспільстві. Зважаючи на розвиток інформаційного простору, більшість міжособистісних комунікативних зв'язків між правоохоронними, правозахисними та судовими органами переходять в інтернет.

Метою статті є дослідження питань, пов'язаних зі значенням інтернету для оперативної і результативної правової комунікації між правоохоронними, правозахисними та судовими органами.

Виклад основного матеріалу дослідження. Зважаючи на розповсюдження такої загальносвітової інформаційної системи, як інтернет, усе складніше уявити сучасне інформаційне суспільство, у якого відсутня можливість приєднатися до даної інформаційної мережі.

(C) M. А. Погосян, 2020 
Н. Івакіна зазначає, що мова закону виконує конструктивну й комунікативну функції. Мова права несе ще й специфічну функцію, яка визначає призначення права регулювати суспільні відносини. Доносячи волю законодавця до юридичних та фізичних осіб, право через мову цілеспрямовано впливає на свідомість людини, спонукає їі до необхідних дій. І це головне. Основна функція мови права - функція повинності (реалізується під час винесення рішень та вироків; в усному мовленні під час діалогу судді та того, кого допитують) [1, с. 1]. Нині в Україні необхідні правоохоронні, правозахисні та судові органи, у яких державні службовці: по-перше, ставляться до правової комунікації як до особистісної цінності; по-друге, володіють культурою і технологіями різноманітних комунікацій; по-трете, професійно використовують сучасні засоби оновлення комунікативного досвіду.

О. Рак зазначає, що дуже важливо, щоб працювала політика «одного голосу», щоб держава у сфері комунікацій працювала як одне ціле, як система [2]. Окрім того, практика свідчить, що окремі відомства досить формально ставляться до соціальних мереж як інструменту зворотного зв'язку.

Правова комунікація правоохоронних, правозахисних та судових органів є індикатором рівня демократії в суспільстві. В умовах військових дій та реформування всіх сфер життєдіяльності необхідний постійний дієвий діалог між правоохоронними, правозахисними та судовими органами. У свою чергу, партнерська співпраця та постійний публічний діалог між правоохоронними, правозахисними та судовими органами розвивають правову, демократичну та соціальну державу. Так, першочерговою невід’ємною складовою частиною всієї діяльності держави повинна бути правова комунікація, що відповідає сучасним інформаційно-комунікаційним технологіям.

У цьому сенсі життєвий світ людини є безперервним споживачем інформації, яка «просіюється» крізь сито стереотипів поведінки, сприйняття, тлумачення для того, щоб бути відкинутою або сприяти трансформації наявних стереотипів у бік більшої адекватності актуальній ситуації. Інформаційний простір включає безліч життєвих світів окремих соціальних чинників, але водночас не зводиться до жодного з них, оскільки виступає зовнішнім щодо індивіда джерелом, інформація з якого потребує рефлексії й інтеріоризації [3].

Специфіка управління в рамках сучасного суспільства з позицій комунікаційного підходу полягає у формуванні засобів електронної комунікації, що сприяють подоланню інформаційним простором рамок між державними суб'єктами, утворенню транснаціонального інформаційного простору [4]. Інформаційний простір, утворений з безлічі комунікативних каналів, полегшує процес отримання інформації, водночас спричиняє утруднення для раціоналізації правової комунікації між правоохоронними, правозахисними та судовими органами.

Сучасну демократичну політичну систему неможливо уявити без такого комунікативного каналу, як інтернет-комунікації, які надають реальну можливість зворотного зв'язку [5, с. 14]. На думку В. Култигіна, інтернет - це не відокремлений «віртуальний світ», це - додаток до світу реального [6]. Органи державної влади, які отримали інтернет, мають можливість знайти простір для творчого самовираження. 
Як уже зазначалося, необхідну інформацію про діяльність органів державної влади нині можна отримати через інтернет. Порівняно з іншими інформаційними ресурсами до переваг обміну інформацією через інтернет варто віднести: по-перше, передання в інтерактивному режимі інформації великого обсягу та з високою швидкістю; по-друге, оперативне донесення інформації; по-третє, демократичність зазначеного ресурсу.

Проте натепер не всі переваги інтернету як одного з ефективних напрямів правової комунікації між правоохоронними, правозахисними та судовими органами використовуються.Нинізначнуувагуорганидержавноївладиприділяютьупровадженню інформаційних технологій із метою підвищення рівня правової комунікації.

Так, основним чинником, що структурує і міняє інформаційний простір постіндустріального суспільства, є застосування засобів електронної комунікації, передусім інтернету. Оскільки глобалізований інформаційний простір діє на всі сфери суспільного життя, то особливий інтерес викликає з'ясування тієї ролі, яку відіграють засоби електронної комунікації у процесах функціонування соціальних інститутів і життєдіяльності окремих індивідів [7]. Для підвищення ефективності правової комунікації необхідно залучати її сучасні канали. Вагому роль у продукуванні та поширенні інформації відіграє інтернет, який є віртуальним простором, де правоохоронні, правозахисні та судові органи можуть здійснювати постійний інформаційний пошук та створювати власний контент.

У науковій літературі акцентується увага на різних ознаках електронної комунікації. Так, О. Долгополов порівнює інтернет-комунікації зі спілкуванням і наголошує, що останнє не опосередковане комп'ютером: «Мережа не є безпосередньою копією реального життя, вона має свої функціональні домінанти, зокрема такі, як зміна суб'єктно-об’єктних відносин, особливості мотивації користувачів, включення до процесів комунікації лише деяких соціальних груп, технологічні детермінанти комунікативної дії. Усі вони спричиняють зміни будь-якого об’єкта, який приходить в онлайн із оффлайну, а також характерні властивості тих явищ, які виникають безпосередньо в мережевому просторі» [8]. Зазначені особливості, на думку С. Матвєєвої, дозволяють розглядати інтернет як особливий вид комунікативного простору, основу якого становить синтез традиційних і специфічних законів комунікації взагалі та мовленнєвої комунікації зокрема [9, с. 25].

Водночас С. Матвєєва найбільш важливими характеристиками інтернету як комунікативного середовища вважає: зумовленість соціальними чинниками; особливу відкритість; інтерактивність; процесуальність; розширення (порівняно із традиційним уявленням про комунікацію) діапазону каналів зв'язку й особливу їхню комплексну взаємодію [9, с. 25]. Цей перелік ознак не є вичерпним.

Різні дослідники $[10 ; 11 ; 12 ; 13]$ виокремлюють інші ознаки інтернет-комунікації, які можна подати у вигляді такого переліку: відбувається в новому інформаційному просторі, який характеризується великою кількістю суб'єктів спілкування та їхньою взаємодією; суб’єкт водночас виконує багато ролей, існує в багатьох реальностях; заснована на принципах актуальності, доступності, інтерактивності, автономності й інтертекстуальності; дистантність, розділення в часі та просторі, опосередкованість комп'ютером; використовує нову форму мови - усно-писемну, 
яка специфічно впливає на нормотворення, жанротворення та реалізацію всієї комунікації в інтернеті.

На думку I. Остапенко, інтернет-комунікація характеризується такими особливостями: активність/пасивність соціального суб'єкта інформаційного світу; «розірваність»/гармонійність соціального буття людини інформаційного суспільства; суперечності/погодження змісту соціального впливу в інформаційному світі. На відміну від звичайної реальності, інтернет-середовищу притаманна значно більша соціальна невизначеність завдяки динаміці, принциповій безмежності, наявності великої різноманітності можливостей комунікації. Якщо буття людини в соціальному світі залишається відносно структурованим, то його «віртуальне життя», яке не має звичних рамок для самокатегоризації, ставить необхідною умовою існування вирішення завдання самовизначення, самопрезентації та пошуку ідентичності [14]. Проблеми та реалії нашого суспільства впливають на соціальну невизначеність інтернет-середовища. Адже процеси правової комунікації між правоохоронними, правозахисними та судовими органами відбуваються в контексті реально-візуального світу і навпаки.

Серед психологічних особливостей інтернет-комунікації в роботах Ю. Бабаєвої, О. Смислової, А. Войскунського, Е. Бєлінської, А. Жичкиної, Т. Тайлера, П. Вейлес та інших виокремлюються такі характеристики: відсутність матеріальних кордонів сприяє здійсненню комунікації із представниками різних культур, забезпечує можливість як групової, так і міжособистісної взаємодії; відсутність психологічного ризику віртуального характеру комунікації дозволяє користувачу відкрито виражати себе, використовувати водночас максимум мовних засобів, розробляти та практично випробовувати різні комунікативні стратегії, що сприяють встановленню взаєморозуміння із представниками інших культур; конструювання власної ідентичності і зміна способів самопрезентації в середовищі інтернету сприяють розвитку творчого ставлення до мови й мовлення, за допомогою яких здійснюється самоактуалізація особистості; знижена чутливість емоційного впливу сприятливо впливає на розвиток лінгвістичного компонента полікультурної мовної особистості завдяки актуалізації проблеми свідомого й реального добору мовних засобів для досягнення комунікативних цілей [15].

Г. Почепцов наголошує, що інформаційні потоки в інтернеті, на відміну від звичайних, ніколи не завершуються, адже завжди можна повернутися до старих матеріалів. Інтернет є водночас і свіжою газетою, і бібліотекою, де зберігаються всі минулі номери. Це створює не просто інформаційне середовище, а інформаційно збагачене середовище [16, с. 92]. Соціальні мережі перетворилися на один із дієвих інструментів правової комунікації, зокрема в контексті обміну інформацією між правоохоронними, правозахисними та судовими органами. Цей канал масової комунікації надає змогу збільшувати обсяги інформації, нарощувати інформаційні ресурси, розширювати комунікативний простір.

3 погляду активної взаємодії правоохоронних, правозахисних та судових органів перспективною є інтеграція суб'єктів державно-управлінської діяльності один з одним у мережевому середовищі. Зазначене підтверджується тим, що, по-перше, робота державних органів у секторі соціальних мереж формує новий тип взає- 
модії, змінює культуру спілкування, стиль стосунків. Соціальні мережі Twitter та Facebook дістали назву «цифрова дипломатія». Цифрова дипломатія є мистецтвом державного управління XXI ст. В експертних колах та засобах масової інформації її називають, наприклад, твіттер-дипломатією, електронною дипломатією, онлайн-дипломатією тощо.

По-друге, соціальні мережі є платформою для обміну інформацією, пов'язаною із суспільно важливими питаннями.

По-третє, діяльність правоохоронних, правозахисних та судових органів у соціальних мережах відкриває додаткові шляхи до побудови ефективної правової комунікації. Серед провідних шляхів доцільно звернути увагу на такі, як: створення блогів з обговорення суспільно значущих питань; доступ до державної інформації тощо.

Що стосується послуг, які надаються за допомогою інтернету, необхідно звернути увагу на думку авторів монографії [17]. Так, до основних послуг належать: електронна пошта (e-mail, е-пошта) - найбільш поширений та дешевий засіб листування й обміну невеликими за обсягом блоками будь-якої інформації; група новин - засіб надання інформації для загального огляду (телеконференції, електронні дошки оголошень тощо); передача файлів (сервіс FTP - File Transfer Protocol) засіб пошуку та пересилання будь-яких інформаційних файлів, без огляду на їхній зміст і призначення; www («Усесвітнє павутиння») - послуга доступу та надання гіпертекстових документів, які ще називають вебсторінками.

Із зростанням популярності соціальних мереж зростає важливість присутності в цьому сегменті правової комунікації правоохоронних, правозахисних та судових органів. Тому влада дедалі уважніше ставиться до свого позиціонування в соціальних мережах.

Зважаючи на євроінтеграційні прагнення нашої держави, варто акцентувати увагу, що найбільш дієвим способом правової комунікації між правоохоронними, правозахисними та судовими органами, який здійснюється за допомогою впровадження та використання сучасних інформаційних технологій, є розміщення та періодичне оновлення інформації на вебсайтах зазначених органів. Правова комунікація за допомогою вебсайтів підвищує ефективність та прозорість діяльності правоохоронних, правозахисних та судових органів.

I. Корж зазначає, що вебсайт є найбільш ефективним способом надання інформації за допомогою інтернету. Нині уявити собі державний орган чи орган місцевого самоврядування, який не має власного вебсайту, неможливо $[18$, с. 10]. Однак не в усіх органах держави, як показує практика, вебсайти функціонують ефективно та наповнені контентом, який відповідав би вимогам часу. Зазначене зумовлено тим, що в Україні немає нормативно-правового акта, у якому містилися б положення щодо врегулювання правової комунікації між правоохоронними, правозахисними та судовими органами, зокрема через інтернет.

Висновки. Сучасне інформатизоване суспільство кардинально міняє структуру обміну і використання інформацією. В умовах безперервної низки комунікативних актів, якими розмічений графік роботи правоохоронних, правозахисних та судових органів, актуалізується питання вибудовування раціональної стратегії, що передбачає готовність до правової комунікації. Провідною метою пра- 
вової комунікації є оприлюднення своєчасної, всебічної, достовірної інформації про діяльність правоохоронних, правозахисних та судових органів, з дотриманням водночас вимог щодо збереження державної й інших видів таємниць. Провідним засобом запобігання комунікаційним ризикам у сучасному інформаційному просторі є інтернет, який забезпечує доступ до інформаційного простору для всіх правоохоронних, правозахисних та судових органів. В умовах реформування державної влади в Україні провідне місце належить правовій комунікації між правоохоронними, правозахисними та судовими органами, що реалізується за допомогою їхніх вебсайтів. Проте сайти правоохоронних, правозахисних та судових органів мають бути змістовно наповненими та відповідати вимогам сучасності. Адже своєчасна, усебічна та достовірна інформація на вебсайтах є запорукою успішної взаємодії правоохоронних, правозахисних та судових органів, що ефективно сприяє вирішенню актуальних проблемних питань різного рівня. За останні роки правоохоронні, правозахисні та судові органи вдосконалили свої офіційні вебсайти, однак більшість ресурсів ще не виконують належним чином вимоги про розміщення інформації. Зазначене зумовлено тим, що досі не ухвалений окремий закон, який би регулював питання, пов'язані із правовою комунікацією між правоохоронним, правозахисними та судовими органами. Зазначене зволікання перешкоджає нашій державу бути повноцінним представником у світовому інформаційному просторі. Нагальним питанням має стати ухвалення закону, у якому були б визначені засади, пов'язані із правовою комунікацією між правоохоронними, правозахисними та судовими органами, а також інтернету як основного напряму покращення комунікації.

\section{Jimepamypa}

1. Ивакина Н. Профессиональная речь юриста : учебное пособие. Москва : БЭК, 1997. 348 с.

2. Рак О. Політико-комунікаційні впливи на суспільство та способи їх реалізації через засоби масової інформації. Освіта регіону: політологія, психологія, комунікації. 2012. № 3. С. 188-191.

3. Костирєв А. Роль засобів масової інформації у процесі демократичного розвитку суспільства : автореф. дис. ... канд. політ. наук. Київ, 2003. 20 с.

4. Клименко І., Линьок К. Технології електронного врядування. Київ : Центр сприяння інституційному розвитку державної служби, 2006. $192 \mathrm{c}$.

5. Радченко О. Роль ынтернет-комунікацій у політичній взаємодії в Україні : автореф. дис. ... канд. політ. наук. Одеса, 2012.18 с.

6. Култыгин В. «Что ты видишь за окном? - рабочий стол». Интернет и фольклор : сборник статей / сост. А. Захаров. Москва : ГРЦРФ, 2009. URL: http://magazines.russ.ru/october/ 2010/7/ku13pr.html.

7. Ненашев А. Средства электронной коммуникации в структуре социума. Саратов : ФГОУ ВПО «Саратовский ГАУ», 2008. 108 с.

8. Долгополов А. Свойства и признаки объектов гуманитарного Интернета. URL: http://www.relga.ru/Environ/WebObjects/tguwww.woa/wa/Main?textid=279.

9. Матвєєва С. Сайт як жанр інтернет-комунікації (на матеріалі персональних сайтів учених) : дис.. ... канд. філол. наук. Луганськ, 2006. 212 с.

10. Носов Н. Виртуальная психология. Москва : Аграфа, 2000. 432 с.

11. Розина И. Теория и практика компьютерно-опосредованной коммуникации в России: состояние и перспективы. Теория коммуникащии \& прикладная коммуникация : вестник Российской ком.муникативной ассоциации : сборник научных трудов. 2002. Вып. 1. С. 185-192.

12. Коноплицький С. Соціальні аспекти комунікації в мережі Інтернет: феноменологічний аналіз : дис.. ... канд. соціол. наук. Київ, 2006. 154 с. 
13. Переломов А. Інтернет як канал зв'язку переклад-опосередкованої комунікації в мультилінгвальних та мультикультурних контекстах. Філологічні трактати. 2010. № 3. С. 183-187.

14. Остапенко И. Гендерная идентичность и самопрезентация в интернет-коммуникации : социально-философский анализ : автореф. дис. ... канд. фил. наук. Ростов-на-Дону, 2004. 20 с.

15. Кущенко О. Формування культури інтернет-комунікації майбутніх учителів засобами інформаційно-комунікаційних технологій : дис.. ... канд. пед. наук. Дніпропетровськ, 2008. 249 с.

16. Почепцов Г. Від Facebook'y і гламуру до Wikileaks : медіакомунікації. 2-ге вид. Київ : Спадщина, 2014. 464 с.

17. Е-боротьба в інформаційних війнах та інформаційне право : монографія / за ред. М. Швеця. Київ : НДЦПІ АПрН України, 2007. 234 с.

18. Корж I. Вебсайт органів державної влади та органів місцевого самоврядування: механізм доступу до публічної інформації. Інфорлація і право. 2018. № 2 (25). С. 9-16.

\section{Анотація}

Погосян М. А. Мережа Інтернет - сучасний напрям оптимізації правової комунікації між правоохоронними, правозахисними та судовими органами. - Стаття.

У статті акцентовано увагу, що зі зміною інформаційних технологій та їхньої ролі в життєдіяльності суспільства значно розширилася сфера обміну інформацією, що актуалізувало розвиток інноваційних комунікацій. Підкреслено, що розбудова правової держави, реформування судів різних інстанцій, правоохоронних та правозахисних органів зумовлюють нагальний розвиток дієвої правової комунікації між зазначеними органами. Упровадження електронної комерції свідчить про відсутність у нашій державі належного нормативно-правового регулювання та наукового забезпечення правової комунікації між правоохоронними, правозахисними та судовими органами. Наголошено, що провідною метою правової комунікації є оприлюднення своєчасної, всебічної та достовірної інформації про діяльність правоохоронних, правозахисних та судових органів, з дотриманням водночас вимог щодо збереження державної й інших видів таємниць. Зазначено, що провідним засобом запобігання комунікаційним ризикам у сучасному інформаційному просторі є інтернет, який забезпечує доступ до інформаційного простору для всіх правоохоронних, правозахисних та судових органів. Зауважено, що в умовах реформування державної влади провідне місце належить правовій комунікації між правоохоронними, правозахисними та судовими органами, що реалізується за допомогою їхніх вебсайтів, які мають бути змістовно наповненими та відповідати вимогам сучасності. Зроблено висновок про те, що досі не ухвалений окремий закон, який би регулював питання, пов'язані із правовою комунікацією між правоохоронним, правозахисними та судовими органами. Нагальним питанням має стати ухвалення закону, у якому були б визначені засади, пов'язані із правовою комунікацією між правоохоронними, правозахисними та судовими органами, а також інтернету як основного напряму підвищення комунікації.

Ключові слова: право, комунікація, правова комунікація, інформаційний простір, Інтернет, суб'єкти правової комунікації, правоохоронні органи, правозахисні органи, органи судової влади

\section{Summary}

Pohosian M. A. The Internet is a modern direction of optimization of judicial communication between law-enforcement bodies, human rights bodies and law courts. - Article.

The article points out that the change in informational technologies and in their role in the life of the society is accompanied by the expansion of the sphere of information exchange which brought about the development of innovational communications. It is underlined that creating a rule-of-law state, reforming courts of different authority, law-enforcement and human rights bodies determine the current development of effective judicial communication between the bodies mentioned above. Introduction of e-commerce testifies that in our state appropriate regulatory environment and scientific support of judicial communication between law-enforcement bodies, human rights bodies and law courts is absent. The paper stresses that the chief aim of judicial communication is revelation of timely, comprehensive and reliable information about the activity of law-enforcement bodies, human rights bodies and law courts, at the same time the requirements concerning the preservation of state secrecy and other kinds of secrecy should be observed. The article states that the main means of prevention of communicational risks in modern informational space is Internet which provides access to informational space for all law-enforcement bodies, human rights bodies and law courts. It is noted that under the conditions of reformation of state authority the leading role belongs to judicial communication between law-enforcement bodies, human rights bodies 
and law courts. This communication is realized by means of their web-sites which should have substantive content and should correspond to modern conditions. The author concludes that a law that would regulate the communication between law-enforcement bodies, human rights bodies and law courts is not adopted yet. The urgent issue should be the adoption of the Law which would define the principles connected with judicial communication between law-enforcement bodies, human rights bodies and law courts and with Internet as the main direction of enhancing the communication

Key words: law, communication, judicial communication, informational space, Internet, subjects of judicial communication, law-enforcement bodies, human rights bodies, law courts. 